\title{
PERBANDINGAN TINGKAT ANSIETAS MAHASISWA KEDOKTERAN YANG DITERIMA MELALUI JALUR SNMPTN, SBMPTN DAN MANDIRI DAN KECENDERUNGAN CABIN FEVER DALAM MELAKSANAKAN UJIAN BLOK PADA MASA PANDEMI
}

\author{
Nathania Maulina, Margarita Maria Maramis, David Sontani Perdanakusuma, \\ Lilik Djuari \\ Fakultas Kedokteran Universitas Airlangga, Surabaya, Indonesia \\ Email: nathaniabalaw@gmail.com, margarit@indosat.net.id, dperdanakusuma@yahoo.c \\ om, lilikdjuari@gmail.com
}

\begin{abstract}
Abstrak
Penelitian ini bertujuan untuk membandingkan tingkat kecemasan mahasiswa kedokteran yang diterima melalui jalur SNMPTN, SBMPTN dan jalur mandiri. Metode yang digunakan dalam penelitian ini adalah penelitian observasional analitik dengan desain cross sectional yang melibatkan 244 mahasiswa Fakultas Kedokteran Universitas Airlangga angkatan 2020. Data diperoleh melalui pengisian kuesioner Cabin Fever Scale dan State Trait Anxiety Inventory yang dilakukan sebanyak dua kali. , yaitu sebelum dan sesudah ujian blok. Hasil: Sebagian besar siswa yang diterima melalui jalur SNMPTN $(90,4 \%)$, SBMPTN $(89,3 \%)$, dan mandiri $(89,7 \%)$ merasa cukup cemas. Sebelum menghadapi ujian blok, mayoritas siswa yang diterima melalui jalur SNMPTN $(90,4 \%)$, SBMPTN $(94,7 \%)$, dan mandiri $(89,8 \%)$ merasa cukup cemas. Setelah menghadapi ujian blok, mayoritas siswa yang diterima melalui jalur SNMPTN (92,3\%), SBMPTN $(88,0 \%)$, dan mandiri $(83,8 \%)$ merasa cukup cemas. Tidak ada hubungan antara jalur masuk dengan tingkat kecemasan sebelum dan sesudah ujian blok ( $\mathrm{p}=$ $0,493$ dan $\mathrm{p}=0,442)$. Sebagian besar siswa $(50,8 \%)$ mengalami demam kabin yang parah. Ada hubungan antara cabin fever dengan kecemasan sebelum melakukan tes blok ( $\mathrm{p}<0,001)$, tetapi tidak dengan kecemasan setelah melakukan tes blok $(\mathrm{p}=0,387)$. Tidak ada hubungan antara jalur penerimaan dengan tingkat kecemasan sebelum dan sesudah ujian blok. Ada hubungan antara demam kabin dengan kecemasan sebelum melakukan tes blok, tetapi tidak dengan kecemasan setelah melakukan tes blok.
\end{abstract}

Kata Kunci : jalur penerimaan; kecemasan; cabin fever

\section{Abstract}

This study aims to compare the anxiety levels of medical students who are accepted through the SNMPTN, SBMPTN and independent channels. The method used in this research is an observational analytic study with a cross sectional design involving 244 students of the Faculty of Medicine, Airlangga University batch 2020. Data were obtained through filling out Cabin Fever Scale and State Trait Anxiety Inventory questionnaires which were carried out

$\begin{array}{ll}\text { How to cite: } & \text { Maulina. N. et.al (2021). Perbandingan Tingkat Ansietas Mahasiswa Kedokteran yang diterima } \\ & \text { Melalui Jalur SNMPTN, SBMPTN dan Mandiri dan Kecenderungan Cabin Fever dalam } \\ & \text { Melaksanakan Ujian Blok pada Masa Pandemi. Syntax Literate: Jurnal Ilmiah Indonesia, 6(2). } \\ \text { E-ISSN: } & 2548-1398 \\ \text { Published by: } & \text { Ridwan Institute }\end{array}$


Nathania Maulina, Margarita Maria Maramis, David Sontani Perdanakusuma, Lilik Djuari

twice, namely before and after the block exam. Results: The majority of students who were accepted through the SNMPTN (90.4\%), SBMPTN (89.3\%), and independent (89.7\%) felt quite anxious. Before facing the block exam, the majority of students who were accepted through the SNMPTN (90.4\%), SBMPTN (94.7\%), and independent (89.8\%) felt quite anxious. After facing the block exam, the majority of students who were accepted through the SNMPTN (92.3\%), SBMPTN (88.0\%), and independent (83.8\%) felt quite anxious. There was no correlation between the admissions path and the level of anxiety before and after the block exam $(p=0.493$ and $p=0.442)$. The majority of students $(50.8 \%)$ experienced severe cabin fever. There was a correlation between cabin fever and anxiety before doing the block test $(p<0.001)$, but not with anxiety after doing the block test $(p=0.387)$. There is no correlation between the admissions path and the level of anxiety before and after the block exam. There is a correlation between cabin fever and anxiety before doing the block test, but not with anxiety after doing the block test.

Keywords: admissions pathway; anxiety; cabin fever

Received: 2021-10-20; Accepted: 2021-11-05; Published: 2021-11-20

\section{Pendahuluan}

Ansietas adalah respons alami tubuh manusia saat merasa stres ataupun tertekan. Setiap individu memiliki tingkat kecemasan, kekhawatiran yang berbeda antar satu sama lain dan timbul oleh penyebab yang tidak spesifik. Menurut Kusuma, dalam Hapilan, Kusmaedi, dan Fitri (2017) bahwa kecemasan adalah suatu keadaan yang ditandai dengan perasaan ketakutan yang disertai dengan tanda somatik. Terjadi hiperaktifitas sistem syaraf otonom dan gejala yang tidak spesifik yang sering ditemukan dan sering kali merupakan suatu emosi yang normal.

Jalur penerimaan mahasiswa fakultas kedokteran UNAIR dibagi menjadi 3 jalur seleksi, yaitu jalur SNMPTN, jalur SBMPTN dan jalur Mandiri. SNMPTN merupakan jalur undangan untuk siswa/i calon mahasiswa yang dianggap berkompetensi berdasarkan nilai rapor selama duduk di bangku SMA. Siswa yang diterima jalur SNMPTN dapat dianggap sebagai siswa yang cerdas secara akademik dan merupakan siswa unggulan di sekolah. Jalur kedua adalah SBMPTN yang merupakan seleksi mahasiswa yang diadakan serentak oleh beberapa perguruan tinggi negeri di seluruh Indonesia. Pada jalur ujian tulis serentak ini, mahasiswa yang diterima dituntut mampu bersaing dengan mahasiswa lain yang diterima di perguruan tinggi tanpa melalui tes. Jalur penerimaan mahasiswa terakhir adalah jalur mandiri. Jalur mandiri merupakan seleksi mahasiswa baru melalui ujian tulis berdasarkan minat dan kemampuan calon mahasiswa secara finansial dengan tetap memperhatikan kemampuan dan kompetensi. Seleksi mahasiswa ini dilaksanakan dan diselenggarakan secara mandiri oleh Universitas Airlangga.

Intelligence Quotient (IQ) adalah skor total yang diperoleh dari serangkaian tes standar yang dirancang untuk menilai kecerdasan manusia (Braaten \& Norman, 2006). Ada paradigma yang menyatakan bahwa tingkat intelejensia berpengaruh terhadap 
Perbandingan Tingkat Ansietas Mahasiswa Kedokteran yang diterima Melalui Jalur SNMPTN, SBMPTN dan Mandiri dan Kecenderungan Cabin Fever dalam Melaksanakan Ujian Blok pada Masa Pandemi

kelolosan dalam jalur penerimaan mahasiswa baru (Munawaroh, 2015). Disebutkan bahwa mahasiswa yang diterima melalui jalur SNMPTN cenderung memiliki tingkat kecerdasan intelektual lebih tinggi daripada mahasiswa yang diterima dengan jalur kemitraan. Penelitian oleh Handayani dan Ludigdo (2013) menunjukkan hubungan positif dan siginifikan antara jalur masuk dengan prestasi belajar mahasiswa. SNMPTN lebih mengutamakan tingkat intelejensia, sehingga tingkat intelejensia dapat berpengaruh terhadap prestasi belajar. Hasil penelitian tersebut sependapat dengan rasionalisasi bahwa keketatan jalur masuk dapat mencerminkan tingkat kecerdasan dan kemampuan mahasiswa dalam prestasi belajar mahasiswa. Penelitian lain oleh Irhas (2017) dan Mawarni (2017) justru menyebutkan tidak adanya perbedaan prestasi akademik dilihat dari jalur penerimaan, baik pada kelompok jalur SNMPTN, SBMPTN dan UM. Hal tersebut menunjukkan bahwa terdapat faktor lain yang mempengaruhi prestasi selain kecerdasan intelektual (IQ), yaitu stabilitas emosi dan kreativitas, faktor kepribadian, lingkungan kampus dan keluarga, serta motivasi belajar (Irhas, 2017, Noor Akbar dan Nur Rachmah, 2020).

Siswa yang baru saja masuk ke jenjang perguruan tinggi akan merasakan masa transisi perubahan lingkungan belajar. Hal ini dapat berpengaruh pada kejiwaan mahasiswa. Tingkat ansietas tiap mahasiswa akan berbeda, tergantung pada bagaimana mekanisme koping yang digunakan untuk menghadapi stressor penyebab kecemasan tersebut, karena semakin tinggi level kecemasan maka perlu adanya mekanisme koping yang di gunakan dalam mengatasi kecemasan yang terjadi (Sumoked, Wowiling, \& Rompas, 2019). Beberapa penelitian menunjukkan bahwa jalur penerimaan mahasiswa baru mempengaruhi tingkat kecemasan mahasiswa. Penelitian Worumi (2017) mendapat gambaran angka kejadian cemas tertinggi pada mahasiswa preklinik Fakultas Kedokteran Universitas Hasanuddin pada jalur masuk penerimaan mahasiswa melalui SBMPTN, namun hasil penelitian Shapariah (2009) tidak menunjukkan perbedaan yang bermakna antara kecemasan mahasiswa yang masuk melalui jalur PMDK, Reguler, dan Swadana. Chairina, Mardijana, dan Fajar Kusuma (n.d.) mengemukakan bahwa terdapat hubungan signifikan antara tingkat kecerdasan dan tingkat kecemasan siswa menjelang UAS, dengan nilai koefisen sebesar 0,620 (negatif) yang berarti antara tingkat kecemasan dan tingkat kecerdasan berhubungan kuat dengan arah berlawanan yakni semakin tinggi kecerdasan siswa semakin rendah tingkat kecemasan saat menjelang UAS dan sebaliknya kecemasan yang tinggi akan menurunkan kemampuan (kecerdasan) dalam belajar.

Dalam perkuliahan di fakultas kedokteran, ujian blok merupakan rutinitas setiap akhir mata kuliah ataupun blok. Ujian merupakan salah satu fokus utama mahasiswa dan dapat menjadi sebuah masalah, karena mahasiswa merasa tertekan dan cemas menghadapi ujian tersebut. Kecemasan menjelang ujian ini disebut dengan test anxiety atau kecemasan ujian. Studi oleh oleh Singh et al., (2012) menunjukkan bahwa level stress dan kortisol saliva pada mahasiswa kedokteran secara signifikan meningkat selama menghadapi ujian. Terdapat beberapa gejala fisik, emosional, dan kognitif jika seseorang kecemasan ujian. Kecemasan ujian berubah menjadi masalah jika kecemasan 
Nathania Maulina, Margarita Maria Maramis, David Sontani Perdanakusuma, Lilik Djuari

menjadi sangat tinggi sehingga mengganggu persiapan dan kinerja ujian. Seperti kesulitan dalam berkonsentrasi, sehingga pemikiran tidak jernih dan lupa materi yang telah di pelajari.

Saat ini, mahasiswa yang mengikuti pendidikan tinggi lebih rentan terhadap gangguan kecemasan yang dapat menurunkan kualitas hidupnya. Hal ini harus segera diatasi karena dapat menyebabkan berbagai efek seperti menurunnya konsentrasi mahasiswa dalam proses pendidikan, dan juga berkaitan dengan pencapaian prestasi belajar yang rendah yang kemudian dapat memicu terjadinya depresi. Hal ini berbahaya karena dapat berujung pada pencederaan diri atau bunuh diri. Oleh karena itu, diperlukan pemahaman yang baik mengenai kecemasan dan hubungannya dengan proses pendidikan sehingga dapat mencegah terjadinya depresi pada mahasiswa (Mirulilalini dan Wayan, 2017).

Saat ini, pandemi COVID-19 telah berdampak pada restrukturisasi kurikulum dan ujian serta perubahan pendidikan klinis yang signifikan pada fakultas kedokteran. Transisi metode pembelajaran dan ujian yang saat ini seluruhnya dilakukan secara daring dapat menjadi stressor dan mengharuskan mahasiswa beradaptasi dengan cepat (Goothy et al., 2020). Studi telah menunjukkan bahwa kesehatan mental mahasiswa kedokteran lebih buruk dibanding populasi umum dan dengan adanya stressor akademik sebagai faktor risiko utama, perubahan pembelajaran akibat pandemi ini akan berefek secara signifikan pada kesehatan mental mahasiswa (O'Byrne, Gavin, \& McNicholas, 2020). Jervis dan Brown (2020) menyatakan bahwa working from home selama social distancing membuat mahasiswa dikelilingi dengan tekanan keluarga yang ekstra, yang dihadapi semua mahasiswa selama pandemi ini. Kondisi ini ditambah dengan format ujian yang baru dan asing dapat menjadi stressor untuk mahasiswa. Terbatasnya aktivitas juga memaksa mahasiswa untuk lebih sering menghabiskan waktu di dalam rumah, menyebabkan risiko terjadinya cabin fever.

Pada dasarnya cabin fever bukanlah kondisi medis yang spesifik, tetapi merupakan istilah awam yang umumnya dipahami untuk merujuk pada kombinasi perasaan cemas, kelesuan, iritabilitas, murung, kebosanan, depresi, atau perasaan tidak puas dalam menanggapi isolasi sosial, cuaca buruk, rutinitas, atau kurangnya stimulasi/aktivitas. Seseorang yang terkena cabin fever mungkin menderita sulit tidur (insomnia) atau sangat mengantuk (hipersomnia). Mereka bahkan mungkin mengembangkan paranoia dan kesulitan dalam pengambilan keputusan yang rasional. Pada ekstremnya, orang mungkin merasa terdorong untuk melepaskan diri dari batasan spasial atau rutinitas terbatas mereka, terlepas dari kondisi eksternal atau biaya untuk diri mereka sendiri atau orang lain. Cabin fever juga dapat menyebabkan kekerasan yang diarahkan pada diri sendiri dan orang lain, termasuk bunuh diri (Crawford, 2021).

Kecemasan ujian juga dapat diberi label sebagai kecemasan antisipatif, kecemasan situasional, atau kecemasan evaluasi. Beberapa kecemasan adalah hal yang normal dan seringkali membantu untuk tetap waspada secara mental dan fisik (Hashmat, 2008). Kecemasan yang dirasakan bisa saja hilang sesudah ujian selesai, namun tidak menutup kemungkinan bahwa setelah ujian blok mahasiswa masih mengalami ansietas. Tingkat 
Perbandingan Tingkat Ansietas Mahasiswa Kedokteran yang diterima Melalui Jalur SNMPTN, SBMPTN dan Mandiri dan Kecenderungan Cabin Fever dalam Melaksanakan Ujian Blok pada Masa Pandemi

ansietas bervariasi mulai dari ansietas ringan, ansietas sedang, ansietas berat dan dapat menjadi panik atau burnout. Dalam sebuah penelitian terhadap 4.287 siswa di tujuh sekolah kedokteran, tingkat burnout diperkirakan mencapai 49,6\%, dengan hanya 26,5\% yang pulih pada tindak lanjut 1 tahun (Detre, 2003).

Menurut Stuart GW (2005) peningkatan kecemasan tidak selamanya berarti buruk. Jika diarahkan dengan benar maka seseorang dengan peningkatan tingkat kecemasan akan melakukan mekanisme coping yang baik sehingga menghasilkan hasil yang baik. Dengan mengetahui test anxiety, mahasiswa dapat mampu meningkatkan performa sebelum, selama dan sesudah ujian serta meminimalisir dampak dari test anxiety itu sendiri.

Berdasarkan uraian di atas, terlihat bahwa masalah ansietas dalam menghadapi ujian blok merupakan salah satu masalah kesehatan yang penting untuk diperhatikan karena kondisi tersebut dapat mengganggu konsentrasi dan performa mahasiswa dalam menjalani ujian. Diduga jalur penerimaan mahasiswa baru (SNMPTN, SBMPTN, mandiri) dan cabin fever akibat pandemi COVID-19 merupakan faktor yang berpengaruh terhadap kondisi ini. Sampai proposal penelitian ini dibuat, belum pernah dilakukan penelitian yang mengangkat permasalahan ini di FK UNAIR. Hal inilah yang membuat peneliti tertarik untuk melakukan penelitian ini, sekaligus menjadikannya penting untuk dilakukan. Rumusan yang muncul dalam penelitian ini adalah:

1) Bagaimana tingkat ansietas state yang paling banyak diidap oleh mahasiswa FK UNAIR angkatan 2020?

2) Bagaimana tingkat ansietas trait mahasiswa FK UNAIR angkatan 2020 yang diterima melalui SNMPTN, SBMPTN dan Mandiri dalam menghadapi ujian blok?

3) Bagaimana gambaran kecenderungan cabin fever pada mahasiswa FK UNAIR angkatan 2020 ?

4) Apakah ada korelasi cabin fever dengan ansietas mahasiswa pada sebelum dan sesudah ujian blok?

\section{Metode Penelitian}

Jenis penelitian ini adalah penelitian analisis observasional. Rancangan penelitian yang dipilih adalah cross sectional study (studi potong lintang) dengan alat ukur State Trait Anxiety Rating (STAI) dan Cabin Fever Scale dengan desain pre dan post test. Selanjutnya data yang sudah dikumpulkan kemudian dilakukan tahapan pengolahan data yang meliputi editing, coding, dan cleaning.

1) Editing

Tahap ini berupa pengecekan kuesioner dan memastikan kelengkapan dari jawaban responden.

2) Coding

Kuesioner yang telah dilakukan proses editing akan diubah menjadi data yang berbentuk angka. 
Nathania Maulina, Margarita Maria Maramis, David Sontani Perdanakusuma, Lilik Djuari

\section{3) Cleaning}

Proses pengecekan kembali data yang sudah di entry dan melakukan koreksi bila ada kesalahan selama analisis sehingga dapat segera dilakukan perbaikan. Selanjutnya data dikelompokkan berdasarkan variabel penelitian.

\section{Pembahasan}

Tingkat kecemasan dasar mahasiswa kedokteran yang diterima melalui jalur SNMPTN, SBMPTN, dan Mandiri

Hasil penelitian ini mendapati bahwa pada mahasiswa yang diterima melalui jalur SNMPTN, sebanyak 1,9\% tidak mengalami ansietas, 90,4\% mengalami ansietas pada kategori cukup cemas, dan 7,7\% mengalami ansietas pada kategori sangat cemas. Pada mahasiswa yang diterima melalui jalur SBMPTN, sebanyak 6,7\% tidak mengalami ansietas, 89,3\% mengalami ansietas pada kategori cukup cemas, dan 4,0\% mengalami ansietas pada kategori sangat cemas. Pada mahasiswa yang diterima melalui jalur mandiri, sebanyak 2,6\% tidak mengalami ansietas, 89,7\% mengalami ansietas pada kategori cukup cemas, dan $7,7 \%$ mengalami ansietas pada kategori sangat cemas. Berdasarkan uraian deskriptif tersebut, terlihat bahwa mahasiswa yang diterima melalui jalur SBMPTN memiliki tingkat ansietas yang relatif lebih rendah daripada mahasiswa yang diterima melalui jalur SNMPTN dan mandiri. Mahasiswa yang diterima melalui jalur SNMPTN memiliki tingkat ansietas yang relatif lebih tinggi daripada mahasiswa yang diterima melalui jalur mandiri.

Hasil yang relatif sejalan dengan penelitian ini didapatkan pada sebuah penelitian yang dilakukan oleh Hadiati (2017) di Universitas Diponegoro. Penelitian dengan desani cross sectional yang melibatkan 368 orang mahasiswa kedokteran tersebut bertujuan untuk mengetahui perbedaan tingkat kecemasan dan depresi pada mahasiswa sistem perkuliahan tradisional dengan sistem perkuliahan terintegrasi. Peneltian tersebut menggunakan kuesioner Zung Self-rating Anxiety Scale untuk mengukur tingkat kecemasan. Salah satu hasil penelitian tersebut menunjukkan bahwa mahasiswa yang masuk lewat jalur SNMPTN dan SBMPTN memiliki tingkat kecemasan yang secara signifikan lebih besar daripada mahasiswa yang masuk lewat jalur mandiri $(p=0,036)$.

Hasil serupa juga didapatkan pada sebuah penelitian yang dilakukan oleh Maulana (2014) di Universitas Lampung. Penelitian dengan desani cross sectional yang melibatkan 184 orang mahasiswa kedokteran tersebut bertujuan untuk mengetahui perbedaan tingkat stres antara mahasiswa tahun pertama dan tahun kedua di Fakultas Kedokteran Universitas Lampung. Peneltian tersebut menggunakan kuesioner PSS-10 untuk mengukur tingkat stres. Salah satu hasil penelitian tersebut menunjukkan bahwa tidak terdapat perbedaan tingkat stres yang sgnifikan antara mahasiswa yang masuk lewat jalur SNMPTN, SBMPTN, atau mandiri ( $p>0,05)$. Meskipun demikian, secara deskriptif, mahasiswa yang masuk lewat jalur SNMPTN dan SBMPTN memiliki tingkat stres yang relatif lebih tinggi daripada mahasiswa yang masuk lewat jalur mandiri . 
Perbandingan Tingkat Ansietas Mahasiswa Kedokteran yang diterima Melalui Jalur SNMPTN, SBMPTN dan Mandiri dan Kecenderungan Cabin Fever dalam Melaksanakan Ujian Blok pada Masa Pandemi

Meskipun menunjukkan hasil yang relatif sama, tetapi penelitian Maulana meneliti variabel stres, bukan ansietas. Maulana juga melaporkan bahwa stres dapat menyebabkan ansietas, sehingga hasil penelitian Maulana tetap dibenarkan untuk mendukung hasil penelitian ini.

Hasil berbeda didapatkan pada sebuah penelitian yang dilakukan oleh Hidayanto (2010) di Universitas Sebelas Maret. Penelitian dengan desani cross sectional yang melibatkan 60 orang mahasiswa kedokteran tersebut bertujuan untuk mengetahui perbedaan kecemasan antara mahasiswa kedokteran yang masuk lewat jalur SNMPTN dan mandiri. Peneltian tersebut menggunakan kuesioner L-MMPI dan T-MAS untuk mengukur tingkat kecemasan. Hasil penelitian tersebut menunjukkan bahwa mahasiswa yang masuk lewat jalur mandiri memiliki tingkat kecemasan yang secara signifikan lebih besar daripada mahasiswa yang masuk lewat jalur SNMPTN ( $p<0,05)$. Perbedaan hasil tersebut diduga disebabkan oleh perbedaan instrumen kuesioner yang digunakan.

\section{Perbandingan tingkat ansietas sesaat mahasiswa kedokteran yang diterima melalui jalur SNMPTN, SBMPTN, dan Mandiri dalam menghadapi ujian blok}

Hasil penelitian ini mendapati bahwa pada mahasiswa yang diterima melalui jalur SNMPTN, sebanyak 3,8\% tidak mengalami ansietas, 90,4\% mengalami ansietas pada kategori cukup cemas, dan 5,8\% mengalami ansietas pada kategori sangat cemas sebelum ujian blok. Sedangkan setelah ujan blok, sebanyak 3,8\% tidak mengalami ansietas, 92,3\% mengalami ansietas pada kategori cukup cemas, dan 3,8\% mengalami ansietas pada kategori sangat cemas. Berdasarkan uraian tersebut terlihat bahwa tingkat ansietas mahasiswa yang diterima melalui jalur SNMPTN relatif berkurang setelah menghadapi ujian blok.

Hasil penelitian ini juga mendapati bahwa pada mahasiswa yang diterima melalui jalur SBMPTN, sebanyak 2,7\% tidak mengalami ansietas, 94,7\% mengalami ansietas pada kategori cukup cemas, dan 2,7\% mengalami ansietas pada kategori sangat cemas sebelum ujian blok. Sedangkan setelah ujan blok, sebanyak 10,7\% tidak mengalami ansietas, 88,0\% mengalami ansietas pada kategori cukup cemas, dan 1,3\% mengalami ansietas pada kategori sangat cemas. Berdasarkan uraian tersebut terlihat bahwa tingkat ansietas mahasiswa yang diterima melalui jalur SBMPTN relatif berkurang setelah menghadapi ujian blok.

Pada mahasiswa yang diterima melalui jalur mandiri, sebanyak 7,7\% tidak mengalami ansietas, 86,3\% mengalami ansietas pada kategori cukup cemas, dan 6,0\% mengalami ansietas pada kategori sangat cemas sebelum ujian blok. Sedangkan setelah ujan blok, sebanyak 7,7\% tidak mengalami ansietas, 83,8\% mengalami ansietas pada kategori cukup cemas, dan 8,5\% mengalami ansietas pada kategori sangat cemas. Berdasarkan uraian tersebut terlihat bahwa tingkat ansietas mahasiswa yang diterima melalui jalur mandiri relatif bertambah setelah menghadapi ujian blok.

Data deskriptif yang didapatkan pada penelitian ini menunjukkan bahwa sebelum ujian blok, tingkat ansietas pada kategori tidak cemas dengan jumlah terbanyak 
Nathania Maulina, Margarita Maria Maramis, David Sontani Perdanakusuma, Lilik Djuari

didapatkan pada mahasiswa yang diterima melalui jalur mandiri, tingkat ansiestas pada kategori cukup cemas dengan jumlah terbanyak didapatkan pada mahasiswa yang diterima pada jalur SBMPTN, dan tingkat ansietas pada kategori sangat cemas dengan jumlah terbanyak didapatkan pada mahasiswa yang diterima melalui jalur mandiri. Sementara itu, setelah ujian blok, tingkat ansietas pada kategori tidak cemas dengan jumlah terbanyak didapatkan pada mahasiswa yang diterima melalui jalur SBMPTN, tingkat ansiestas pada kategori cukup cemas dengan jumlah terbanyak didapatkan pada mahasiswa yang diterima pada jalur SNMPTN, dan tingkat ansietas pada kategori sangat cemas dengan jumlah terbanyak didapatkan pada mahasiswa yang diterima melalui jalur mandiri. Terlihat bahwa mahasiswa yang diterima melalui jalur SBMPTN memiliki penurunan tingkat ansietas setelah ujian blok yang relatif lebih besar daripada mahasiswa yang diterima melalui jalur SNMPTN. Tingkat ansietas pada mahasiswa yang diterima melalui jalur mandiri justru mengalami peningkatan setelah ujian blok.

Hasil analisis korelatif penelitian ini mendapati bahwa tidak terdapat korelasi yang signifikan antara jalur penerimaan mahasiswa dengan tingkat ansietas sebelum dan setelah ujian blok (masing-masing $\mathrm{p}=0,493$ dan $\mathrm{p}=0,442$ ). Hasil tersebut juga didukung dengan nilai koefisien korelasi (r) sebesar -0,044 dan 0,049 yang menandakan bahwa korelasi antara jalur penerimaan mahasiswa dengan tingkat ansietas sebelum dan setelah ujian blok memiliki kekuatan yang termasuk dalam kategori sangat lemah, sehingga korelasinya dapat diabaikan. Sampai laporan penelitian ini dibuat, belum terdapat satu pun penelitian yang menganalisis hubungan antara jalur penerimaan mahasiswa dengan tingkat ansietas sebelum dan setelah ujian. Hal ini membuat penelitian ini memiliki nilai kebaruan (novelty) yang dapat menjadi kelebihan utama penelitian ini.

Penelitian ini juga melakukan analisis tingkat ansietas mahasiswa berdasarkan jenis kelamin. Sebelum menjalani ujian blok, mahasiswa perempuan memiliki tingkat ansietas yang relatif lebih tinggi daripada mahasiswa laki-laki sebelum ujian blok. Setelah menjalani ujian blok, mahasiswa perempuan tetap memiliki tingkat ansietas yang relatif lebih tinggi daripada mahasiswa laki-laki, tetapi tingkat ansietas tersebut relatif berkurang dibandingkan dengan tingkat ansietas sebelum menjalani ujian blok.

\section{Kecenderungan kecemasan menghadapi ujian blok}

Salah satu faktor yang diduga memiliki pengaruh terhadap kecemasan mahasiswa dalam menghadapi ujian blok adalah cabin fever, suatu gejala psikologis yang dapat dialami orang ketika mereka tidak dapat meninggalkan rumah dan terlibat dalam interaksi sosial yang saat ini dikaitkan dengan pandemi COVID-19. Penelitian ini mendapati bahwa mayoritas mahasiswa (50,8\%) mengalami cabin fever berat. Berdasarkan domisili, didapatkan bahwa mahasiswa yang berdomisili di Pulau Jawa memiliki proporsi terbesar untuk mengalami cabin fever pada penelitian ini. Namun gambaran deskriptif cabin fever berdasarkan domisili ini tidak dapat digunakan untuk menggambarkan prevalensi cabin fever yang sesungguhnya di Indonesia karena proporsi responden penelitian yang berdomisili di Pulau Jawa pada penelitian ini jauh 
Perbandingan Tingkat Ansietas Mahasiswa Kedokteran yang diterima Melalui Jalur SNMPTN, SBMPTN dan Mandiri dan Kecenderungan Cabin Fever dalam Melaksanakan Ujian Blok pada Masa Pandemi

lebih besar dibandingkan lokasi domisili lainnya.

Beberapa penelitian sebelumnya telah melaporkan bahwa cabin fever berhubungan dengan kejadian kecemasan, terutama pada pelajar dan mahasiswa. Hal ini dilaporkan salah satunya pada penelitian Hawes (2021) di New York, Amerika Serikat. Penelitian dengan desain cross sectional yang melibatkan 451 orang remaja dan dewasa muda tersebut bertujuan untuk mengetahui perubahan tingkat depresi dan kecemasan selama masa pandemi COVID-19. Penelitian tersebut menggunakan Screen for Child Anxiety Related Symptoms untuk mengukur tingkat kecemasan. Penelitian tersebut melaporkan bahwa terdapat dugaan cabin fever berhubungan dengan kecemasan selama masa pandemi COVID-19. Meskipun demikian, penelitian tersebut tidak melakukan analisis statistik terhadap hubungan tersebut . Hasil serupa juga didapatkan pada sebuah penelitian yang dilakukan oleh Chen (2021) di Cina. Penelitian dengan desain kualitatif yang melibatkan 12 orang dewasa muda tersebut bertujuan untuk mengetahui gambaran klinis cabin fever selama masa pandemi COVID-19. Penelitian tersebut melaporkan bahwa kecemasan merupakan salah satu manifestasi klinis utama yang ditemukan pada dewasa muda selama masa pandemi COVID-19 .

\section{Korelasi cabin fever dengan ansietas pada sebelum dan sesudah ujian blok}

Penelitian ini mendapati bahwa terdapat korelasi antara cabin fever dengan kecemasan sebelum melakukan ujian blok ( $\mathrm{p}<0,001)$. Korelasi antara keduanya termasuk dalam kategori lemah dan arah kekuatan positif $(r=0,384)$. Hal ini menunjukkan bahwa semakin berat derajat cabin fever, semakin tinggi juga tingkat kecemasan yang dialami sebelum ujian blok. Karena bersifat korelatif, hasil tersebut juga dapat diartikan bahwa semakin tinggi tingkat kecemasan sebelum ujian blok akan diiringi dengan semakin beratnya derajat cabin fever. Sementara itu, tidak terdapat korelasi antara cabin fever dengan kecemasan setelah melakukan ujian blok ( $p=0,387)$. Hilangnya korelasi tersebut setelah mahasiswa melakukan ujian blok diduga disebabkan berkurangnya kecemasan yang dirasakan karena telah menyelesaikan ujian. Meskipun beberapa mahasiswa masih melaporkan adanya kecemasan, tetapi secara umum skor kecemasan setelah menjalani ujian blok mengalami penurunan. Hingga laporan penelitian ini dibuat, tidak terdapat satu pun penelitian yang meneliti korelasi antara cabin fever dengan kecemasan sebelum atau setelah melakukan ujian pada mahasiswa. Hal ini menjadi kelebihan utama penelitian ini karena memberikan nilai kebaruan (novelty) yang dapat digunakan sebagai landasan dari penelitian-penelitian selanjutnya dengan permasalahan serupa.

\section{Kesimpulan}

1) Mahasiswa FK UNAIR angkatan 2020 mayoritas mendapatkan hasil skor 49,24 yang berarti cukup cemas. Dengan minimal skor 31 yang menunjukkan hasil tidak cemas dan maksimal skor 80 yang menunjukkan bahwa secara dasar mahasiswa merasakan ansietas sangat cemas.

2) Mahasiswa FK UNAIR angkatan 2020 yang diterima melalui jalur SNMPTN dan SBMPTN mengalami penurunan tingkat ansietas setelah menghadapi ujian blok, 
Nathania Maulina, Margarita Maria Maramis, David Sontani Perdanakusuma, Lilik Djuari

tetapi tingkat ansietas pada mahasiswa yang diterima melalui jalur mandiri mengalami peningkatan.

3) Mayoritas mahasiswa FK UNAIR angkatan 2020 mengalami cabin fever berat $(50,8 \%)$, cabin fever ringan $(48 \%)$ dan $(1.2 \%)$ tidak mengalami cabin fever.

4) Terdapat korelasi antara cabin fever dengan kecemasan sebelum melakukan ujian blok, tetapi tidak dengan kecemasan setelah melakukan ujian blok pada mahasiswa FK UNAIR angkatan 2020

\section{Daftar Pustaka}

Braaten, E. B., \& Norman, D. (2006). Intelligence (IQ) testing. Pediatrics in Review, 27(11), 403.Google Scholar

Chairina, R. R., Mardijana, A., \& Fajar Kusuma, I. (n.d.). Kecerdasan dan Kecemasan pada Siswa Berhubungan Kuat Menjelang Ujian Akhir Semester (A Strong Relation Between Intelligence and Anxiety of Students Towards Final Semester Exam). Google Scholar

Handayani, A. T., \& Ludigdo, U. (2013). Pengaruh Tingkat Pendidikan Orang Tua dan Jalur Masuk Terhadap Prestasi Belajar Mahasiswa Akuntansi (Studi pada Mahasiswa Jurusan Akuntansi Universitas Brawijaya Malang). Jurnal Ilmiah Mahasiswa FEB, 2(2). Google Scholar

Hapilan, P., Kusmaedi, N., \& Fitri, M. (2017). Perbandingan Tingkat Kecemasan Pelatih dan Atlet Taekwondo. JTIKOR (Jurnal Terapan Ilmu Keolahragaan), 2(1), 38-43. Google Scholar

Irhas, M. (2017). Analisis Kuantitatif Dan Kualitatif Hasil Belajar Mahasiswa Menurut Jalur Penerimaan Mahasiswa Program Studi Pendidikan Biologi FMIPA UNNES. Universitas Negeri Semarang. Google Scholar

Jervis, C. G., \& Brown, L. R. (2020). The prospects of sitting 'end of year'open book exams in the light of COVID-19: A medical student's perspective. Medical Teacher, 42(7), 830-831. Google Scholar

Mawarni, P. I. (2017). Perbandingan Hasil Belajar Akuntansi Mahasiswa Pendidikan Akuntansi Universitas Negeri Surabaya Ditinjau Dari Latar Belakang Pendidikan Dan Jalur Seleksi Masuk Perguruan Tinggi. Jurnal Pendidikan Akuntansi (JPAK), 5(2). Google Scholar

Noor Akbar, S., \& Nur Rachmah, D. (2020). The Comparison of inteligence quotient (IQ) and grade point average (GPA) among undergraduate students in classs of 2015 which has been selected admission throught SNMPTN, SBMPTN, and jalur utama, in study program of psychology, medical faculty, lambung mangkurat university. Google Scholar 
Perbandingan Tingkat Ansietas Mahasiswa Kedokteran yang diterima Melalui Jalur SNMPTN, SBMPTN dan Mandiri dan Kecenderungan Cabin Fever dalam Melaksanakan Ujian Blok pada Masa Pandemi

O’Byrne, L., Gavin, B., \& McNicholas, F. (2020). Medical students and COVID-19: the need for pandemic preparedness. Journal of Medical Ethics, 46(9), 623-626. Google Scholar

Shapariah, S. (2009). Perbedaan kecemasan antara mahasiswa pmdk, reguler, dan swadana semester v di fakultas kedokteran Universitas Sebelas Maret Surakarta. Google Scholar

Singh, R., Goyal, M., Tiwari, S., Ghildiyal, A., Nattu, S. M., \& Das, S. (2012). Effect of examination stress on mood, performance and cortisol levels in medical students. Indian J Physiol Pharmacol, 56(1), 48-55. Google Scholar

Sumoked, A., Wowiling, F., \& Rompas, S. (2019). Hubungan Mekanisme Koping Dengan Kecemasan Pada Mahasiswa Semester Iii Program Studi Ilmu Keperawatan Fakultas Kedokteran Yang Akan Mengikuti Praktek Klinik Keperawatan. Jurnal Keperawatan, 7(1). Google Scholar

\section{Copyright holder:}

Nathania Maulina, Margarita Maria Maramis, David Sontani Perdanakusuma, Lilik Djuari (2021)

First publication right:

Syntax Literate: Jurnal Ilmiah Indonesia

This article is licensed under:

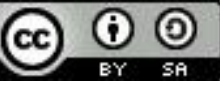

